\title{
Complement fixation by anti-dsDNA antibodies in SLE: measurement by radioimmunoassay and relationship with disease activity
}

C G MACKWORTH-YOUNG, J K H CHAN, C C BUNN, G R V HUGHES, AND A E GHARAVI

From the Rheumatology Unit, Royal Postgraduate Medical School, Hammersmith Hospital, Du Cane Road, London W12

SUMMARY We have developed a sensitive, solid phase radioimmunoassay (RIA) to quantify the amount of complement $\left(C^{\prime}\right)$ fixation by anti-double-stranded DNA (anti-dsDNA) antibodies and have studied sera from 48 patients with systemic lupus erythematosus (SLE). $46 \%$ of the patients were positive in this assay. There was no correlation with serum $C^{\prime}$ levels, and only weak correlation with anti-dsDNA activity as measured by a solid phase RIA. An association was shown between positive values for $C^{\prime}$ fixation by anti-dsDNA antibodies and the presence of active lupus $(\mathrm{p}<0 \cdot 01)$; there was a similar association with the presence of active renal disease in those patients with raised DNA binding $(p<0 \cdot 01)$. Our results suggest that quantitative measurement of $\mathrm{C}^{\prime}$ fixation by anti-dsDNA antibodies may provide information about the pathogenicity of such antibodies in patients with SLE and be a better guide to potential end organ damage than the conventional measurement of DNA binding.

Anti-DNA antibodies have been implicated in tissue damage in SLE, though evidence as to their pathogenicity is conflicting. Particular emphasis has been placed upon the quantification of anti-dsDNA antibodies by the Farr assay. However, serum levels do not always correlate with disease activity, suggesting that pathogenicity may relate to particular properties of these antibodies.

A number of studies have investigated $C^{\prime}$ fixation by anti-DNA antibodies using antinuclear antibody (ANA) or Crithidia luciliae assays: these provide a qualitative and semiquantitative method of determining the ability of such antibodies to activate and fix C3. An ANA assay suggested a close correlation between $C^{\prime}$ fixation and the presence of nephritis. ${ }^{1}$ Crithidia luciliae assays, however, have provided conflicting evidence in this respect. ${ }^{2-5}$ There is also disagreement as to whether or not there is any correlation with the overall antibody level. ${ }^{4-6}$

Accepted for publication 20 August 1985.

Correspondence to Dr C G Mackworth-Young, Cancer Research Center. Tufts University Medical School, New England Medical Center, 171 Harrison Avenue, Boston, Massachusetts 02111, USA.
These methods are semiquantitative. In order to be able to measure $\mathrm{C}^{\prime}$ fixation by anti-dsDNA antibodies in a quantitative fashion we have developed a sensitive, solid phase RIA. With this assay we have studied 48 sera from patients with SLE in order to determine the relationship between the $C^{\prime} \delta$ fixing ability of anti-dsDNA antibodies and disease activity, the presence of active nephritis, and overall $ᄋ$ antibody levels.

\section{Patients, materials, and methods}

PATIENTS

Serum was taken from 48 patients who satisfied the N revised American Rheumatism Association criteria 0 for the presence of SLE. ${ }^{7}$ A clinical and laboratory assessment was made of overall disease activity. In $\frac{\bar{D}}{\bar{D}}$ order to distinguish between current activity of the $\stackrel{\oplus}{\rightarrow}$ disease and organ dysfunction due to previous 0 damage we used criteria for determining disease $\vec{\circ}$ activity described by Huber et al. ${ }^{2}$ Active renal $\stackrel{\odot}{\stackrel{D}{Q}}$ disease was defined as the presence or onset within $\mathbb{\mathbb { D }}$ two months of proteinuria $>1 \mathrm{~g} / 24 \mathrm{~h}$ or an active urinary sediment on microscopy. 
The blood was spun and the serum stored at $-20^{\circ} \mathrm{C}$ within four hours of venesection. Sera from 20 healthy, age and sex matched individuals were used as controls in the same assays; these were negative for antinuclear antibodies by indirect immunofluorescence and for anti-dsDNA antibodies by the Farr assay.

\section{MATERIA LS}

Fresh human serum from 10 healthy individuals was stored at $-70^{\circ} \mathrm{C}$ and used as a source of complement.

Both sheep IgG antihuman IgG and rabbit IgG antihuman C3 were prepared from commercially purchased antisera (Seward Laboratory, UK) by ammonium sulphate precipitation followed by ion exchange chromatography on DEAE 52 (Watman, UK). Radiolabelling with ${ }^{125} \mathrm{INa}$ was performed by the chloramine $\mathrm{T}$ method $^{\mathrm{X}}$ to obtain a specific activity of approximately $0.9 \mu \mathrm{Ci} / \mu \mathrm{g}$.

ASSAY FOR C' FIXING ACTIVITY OF

ANTI-dSDNA ANTIBODIES

Microtitre plates were coated with poly-L-lysin, 50 $\mu \mathrm{g} / \mathrm{ml}(\mathrm{mg} / \mathrm{l})$ in phosphate buffered saline (PBS) $\mathrm{pH}$ $7 \cdot 4,100 \mu \mathrm{l} / \mathrm{well}$, and left at room temperature for two hours. ${ }^{9}$ The plates were washed three times with PBS, $125 \mu \mathrm{l} / \mathrm{well}$, and coated with calf thymus DNA (Sigma, UK), $50 \mu \mathrm{g} / \mathrm{ml}$ in PBS, $100 \mu \mathrm{l} /$ well. In order to remove any single stranded DNA $150 \mu$ l of S1 nuclease in $\mathrm{ZnSO}_{4} / \mathrm{NaCl} /$ glycerol $\mathrm{pH} 4 \cdot 6^{10}$ at 10 units $/ \mathrm{ml}$ was added to each well and incubated at $37^{\circ} \mathrm{C}$ for one hour. The plates were then washed three times with PBS. $125 \mu \mathrm{l}$ of $2 \%$ bovine serum albumin (BSA) (Sigma, UK) in PBS was added to each well. The plates were left at room temperature for two hours and then washed three times with PBS. Test serum decomplemented by incubation at $56^{\circ} \mathrm{C}$ for 30 minutes was added in triplicate at $1 / 60$ dilution in PBS $/ 1 \%$ BSA $(100 \mu \mathrm{l} /$ well $)$ and the plates incubated for one hour at $37^{\circ} \mathrm{C}$ followed by four hours at $4^{\circ} \mathrm{C}$. After three washes with PBS pooled normal fresh human serum diluted $1 / 100$ in complement fixing diluent (Sigma, UK), $100 \mu \mathrm{l} /$ well, was added. The plates were incubated at $37^{\circ} \mathrm{C}$ for one hour and at $4^{\circ} \mathrm{C}$ overnight before being washed three times with PBS. ${ }^{125}$ I-labelled rabbit antihuman C3 was then added $(300000 \mathrm{cpm} /$ well $)$, diluted in $\mathrm{PBS} / 1 \% \mathrm{BSA} / 0.05 \%$ Tween 20 , and the plates left at $37^{\circ} \mathrm{C}$ for one hour followed by $4^{\circ} \mathrm{C}$ overnight. They were then washed five times in PBS, cut manually into individual wells, and counted for one minute in a 16 channel gammacounter (Nuclear Enterprises NE 1600).

ASSAYS FOR ANTI-dSDNA ANTIBODIES

Microtitre plates were coated with poly-L-lysin and calf thymus DNA, digested with S1 nuclease, blocked with BSA, and washed as described above. Test serum decomplemented by incubation at $56^{\circ} \mathrm{C}$ for 30 minutes was added in triplicate at $1 / 60$ dilution in PBS $/ 1 \% \mathrm{BSA}$, and the plates were left at $37^{\circ} \mathrm{C}$ for one hour and at $4^{\circ} \mathrm{C}$ for four hours. After three washes with PBS, ${ }^{125}$ I-labelled sheep antihuman IgG was added (150 $000 \mathrm{cpm} /$ well) diluted in PBS $/ 1 \%$ BSA $/ 0.05 \%$ Tween 20 . The plates were incubated at $37^{\circ} \mathrm{C}$ for one hour and at $4^{\circ} \mathrm{C}$ overnight. They were then washed five times in PBS, cut manually into individual wells, and counted for one minute in a 16 channel gammacounter (Nuclear Enterprises NE 1600).

The Farr assay was performed as previously described (normal range $<30 \%$ ). ${ }^{11}$

\section{ASSAYS FOR COMPLEMENT LEVELS}

Serum C3 and C4 levels were measured antigenetically by the Mancini technique ${ }^{12}$ (single radial immunodiffusion) using commercially obtained antisera to $\mathrm{C} 3$ and $\mathrm{C} 4$ (Seward Laboratory, UK). $\mathrm{CH}_{50}$ was determined by a haemolytic assay. ${ }^{13}$

The results for $\mathrm{C} 3, \mathrm{C} 4$, and $\mathrm{CH}_{50}$ were expressed as percentages of the mean of normal controls, using pooled sera from 35 healthy hospital staff members ( 22 females, 13 males, age range $17-53$ years, mean age 26 years).

\section{S T A T IS T I C S}

Correlation between $C^{\prime}$ fixing values and both anti-DNA antibody levels and $C^{\prime}$ levels was determined by linear regression analysis. Clinical associations were determined by the $\chi^{2}$ test with Yates's correction.

\section{Results}

ASSAY FOR C' FIXING ACTIVITY OF

ANTI-dsDNA ANTIBODIES

The assay produced a wide range of values for sera from SLE patients as compared with normal controls.

To determine the optimal blocking procedure preliminary studies were performed in which plates coated with dsDNA were used after incubation for one hour with $1 \%$ casein, $1 \%$ BSA, $2 \%$ BSA, or $4 \%$ BSA in PBS, or PBS alone, employing selected positive and negative control sera. High 'background' activity was obtained when the plates were blocked with PBS alone; this diminished successively when $1 \%$ casein, $1 \% \mathrm{BSA}$, and $2 \% \mathrm{BSA}$ respectively were used. There was no significant difference between the use of $2 \%$ or $4 \%$ BSA. Increasing the time of incubation to two or four hours also made no significant difference. Incuba- 
tion with $2 \%$ BSA in PBS for one hour was therefore chosen as the blocking step.

Dose-response curves (not shown) consistently showed a peak gradient at a serum dilution of around 1/60: this dilution was therefore used in subsequent experiments.

In initial studies the source of complement was used in various dilutions, and a dilution of $1 / 100$ was shown to give the best discrimination between positive and negative sera in the assay. In a control experiment pooled normal human serum which had been decomplemented (by incubation at $56^{\circ} \mathrm{C}$ for 30 minutes) was used as a source of complement: no significant difference was observed between the results obtained from selected positive and negative test sera (as determined by using fresh pooled normal serum as the complement source).

The lupus sera were studied in several assays alongside sera from the 20 normal controls. Mean counts per minute $(\mathrm{cpm})$ readings for the latter ranged from 2204 to 2357 (standard deviations 161 and 286 respectively) in the different assays. Readings for lupus sera ranged from 1843 to $18169 \mathrm{cpm}$. The intra-assay coefficient of variation was $7.9 \%$.

To take account of interassay variation caused by the decay with time of ${ }^{125} \mathrm{I}$ in the ${ }^{125} \mathrm{I}$-labelled rabbit

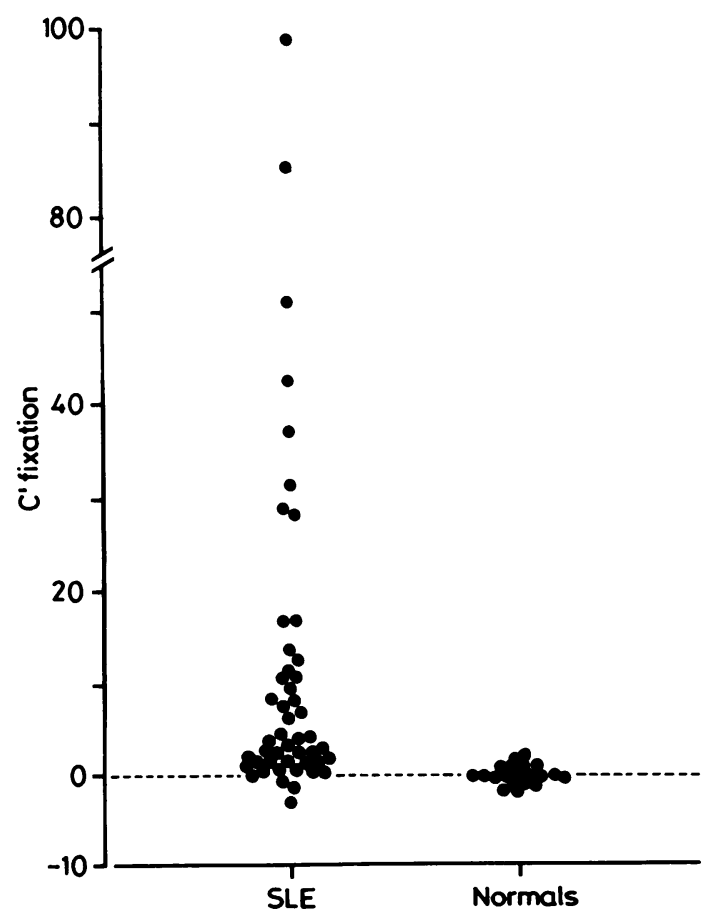

Fig. $1 C^{\prime}$ fixation values in SLE patients and normals, expressed as standard deviations above the mean of the normal controls. antihuman $\mathrm{C} 3$ reagent the degree of $\mathrm{C}^{\prime}$ fixation by anti-dsDNA antibodies was expressed as the num ber of standard deviations (SD) above the mean of the normal controls. Values ranged from $-2 \cdot 2$ too $+98.8 \mathrm{SD}$ (median 3.5) as shown in Fig. 1. Valueso above $+3 \mathrm{SD}$ were considered weakly positive, $\frac{\bar{\sigma}}{\overline{7}}$ those greater than $4 \cdot 6 \mathrm{SD}$ definitely positive. The $\frac{\mathbb{\Phi}}{\Omega}$ interassay coefficient of variation using this methodo was $9.2 \%$.

RELATIONSHIP WITH dSDNA BINDING ACTIVITY

In Fig. 2 the values for $C^{\prime}$ fixation are plottedo against the respective DNA binding (DNAb) valueso as measured by the Farr assay. There is a clusteringer of high $C^{\prime}$ fixing values which correspond to DNAb+ values $>90 \%$. Values for DNAb by the Farr assay $\vec{\omega}$ which are $>85-90 \%$, may not reflect the true relative degree of anti-DNA activity since the assay? at this level is saturated, and such values lie on the plateau portion of the dose-response curve. It waso not therefore possible to determine from these data. whether a correlation existed between $C^{\prime}$ fixing $\vec{\infty}$ values and levels of anti-dsDNA activity. For thișo purpose a solid phase RIA for DNA binding was used. Fig. 3 shows the results obtained for DNA binding plotted against $\mathrm{C}^{\prime}$ fixing activity. There was only weak correlation $(r=0 \cdot 56)$. (Results for anti dsDNA activity are expressed in cpm since the assay was run in one batch. The intra-assay coefficient of variation was $5 \cdot 1 \%$.)

Owing to the extensive clinical experience with test, results from the Farr assay were used for separating patients into groups for clinical correlations.

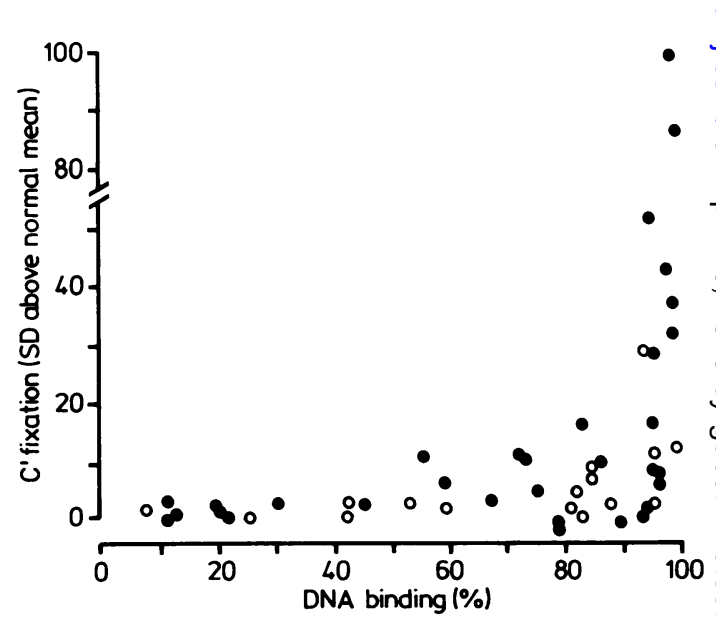

Fig. $2 C^{\prime}$ fixation in SLE patients plotted against DNA binding as measured by the Farr assay. and $\bigcirc$ indicate patients with and without active renal disease respectively. 
RELATIONSHIP WITH C' ACTIVITY

There was no correlation between levels of $\mathrm{C} 3, \mathrm{C} 4$, or total haemolytic complement $\left(\mathrm{CH}_{50}\right)$ and values of $\mathrm{C}^{\prime}$ fixation by anti-dsDNA antibodies. Fig. 4 shows $\mathrm{CH}_{50}$ values plotted against those for $\mathrm{C}^{\prime}$ fixation. Similarly, there was no correlation between the same variables for patients with active nephritis. Absence of correlation was maintained for the whole group of patients and for those with renal disease even when patients with DNAb values $<30 \%$ were excluded.

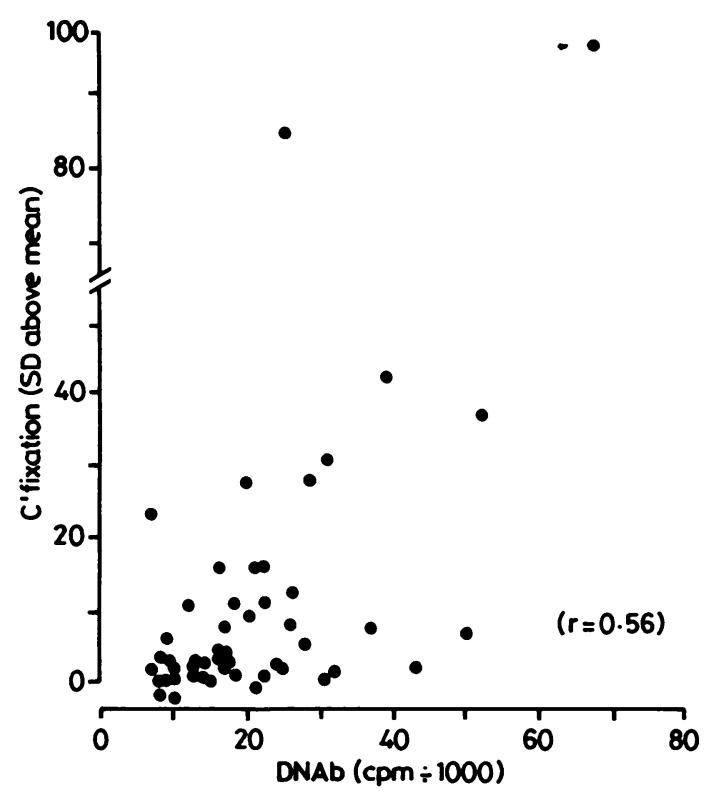

Fig. $3 C^{\prime}$ fixation in SLE patients plotted against level of anti-dsDNA activity (IgG).

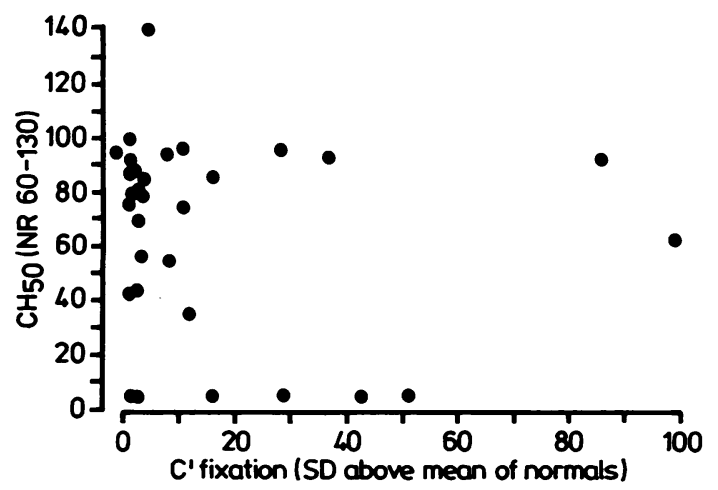

Fig. 4 Total haemolytic complement values for SLE patients plotted against $C^{\prime}$ fixing values.
RELATIONSHIP WITH CLINICAL FEATURES Overall lupus activity was high in 30 patients, of whom 19 had active renal disease. Other objective clinical features included polyarthritis (23 patients), serositis (17), lupus rash (13), neutropenia (20), lymphopenia (six), and thrombocytopenia (11). Twenty two $(46 \%)$ of the total 48 patients had a value for $\mathrm{C}^{\prime}$ fixation $>4.6 \mathrm{SD}$ above the mean of the normal controls: all of these had high overall disease activity and DNAb values $>50 \%$ (Farr assay).

There was a significant association between a definitely positive value for $C^{\prime}$ fixation (>4.6 SD) and the presence of active lupus $(p<0 \cdot 01)$. Overall there was no significant association between positive $\mathrm{C}^{\prime}$ fixation and the presence of active renal disease: however, for patients with a DNAb $>30 \%$ there was a significant association $(p<0.01)$.

Of the 23 patients with DNAb $<80 \%$ (Fig. 2), only two had $\mathrm{C}^{\prime}$ fixing values $>4.6 \mathrm{SD}$ and six had values $>3.0 \mathrm{SD}$ above the control mean; overall lupus activity in five of these patients was high. For the 15 patients with $\mathrm{DNAb}>90 \%$, the $\mathrm{C}^{\prime}$ fixing values ranged from 0.8 to $98.8 \mathrm{SD}$ above the control mean (median 28.4). Lupus activity was high in all of them. Eight had $\mathrm{C}^{\prime}$ fixing values $>20 \mathrm{SD}$ : six of these had active renal disease, and one developed nephritis 16 months later.

\section{Discussion}

Our results show that with the use of a solid phase RIA to quantify $C^{\prime}$ fixation by anti-dsDNA antibodies a wide range of $C^{\prime}$ fixing ability by these antibodies can be detected in sera from patients with SLE. The $C^{\prime}$ fixing property of anti-dsDNA antibodies does not correlate with serum complement levels and correlates only poorly with anti-dsDNA activity. Our data suggest that there is an association between the $C^{\prime}$ fixing property of anti-dsDNA antibodies and the presence of overall active disease.

The use of a solid phase RIA clearly has advantages over the Crithidia luciliae and ANA methods of detecting $\mathrm{C}^{\prime}$ fixation by anti-dsDNA antibodies. The most important of these is that it is more fully quantitative. This has allowed us to determine the relationship between the $C^{\prime}$ fixing ability of antidsDNA and the overall serum level of anti-dsDNA antibodies in SLE sera. Previous assays with Crithidia luciliae have provided conflicting evidence as to whether or not there is a correlation between these two variables. ${ }^{4} 6$ The use of a solid phase RIA for IgG anti-dsDNA activity might reasonably have been expected to give results which showed a strong correlation with $C^{\prime}$ fixation. In fact only weak correlation was obtained, thus emphasising the 
validity of the $\mathrm{C}^{\prime}$ fixing assay and implying a potential importance of $\mathrm{C}^{\prime}$ fixation per se.

The quantitative nature of the $\mathrm{C}^{\prime}$ fixing assay has also allowed us to examine the relationship with serum complement activity. Overall there was no correlation with serum levels of $\mathrm{C} 3, \mathrm{C} 4$, or $\mathrm{CH}_{50}$; nor was there any correlation for patients with active nephritis.

Other work in this laboratory has shown that $\mathrm{C}^{\prime}$ fixing anti-dsDNA antibodies form a classical pathway convertase and recruit factors $B$ and $D$ of the $\mathrm{C} 3 \mathrm{~b}$ amplification loop when they bind to a fixed antigen. ${ }^{4}$ It might have been expected that $C^{\prime}$ levels, in particular $\mathrm{C} 3$, might be low in the presence of a high degree of $C^{\prime}$ fixation by anti-DNA antibodies. Our results may be explained by a high turnover of $\mathrm{C}^{\prime}$ in active lupus patients with increased synthesis and catabolism, ${ }^{14}$ though a difference between $\mathrm{C}^{\prime}$ fixation in vitro and in vivo remains a possibility. It seems unlikely that our findings were a function of overall anti-DNA activity in view of the poor correlation between the latter and $C^{\prime}$ fixing values; furthermore, the absence of correlation between $C^{\prime}$ fixation and $\mathrm{C}^{\prime}$ values was maintained even if patients with a DNAb $<30 \%$ were excluded.

Our finding of an association between positive $\mathrm{C}^{\prime}$ fixing values and active overall disease agrees with the results of work using a Crithidia luciliae assay. ${ }^{2}$ This is consistent with the proposition that antiDNA antibodies, or complexes containing such antibodies, may have a pathogenetic role in lupus. Immune complex deposits in various sites, such as skin, choroid plexus, and kidney, have been shown to contain anti-DNA antibodies, ${ }^{15-17}$ and it is likely that the pathogenicity of such complexes depends on their ability to fix $C^{\prime}$. However, work with ANA and Crithidia luciliae immunofluorescence has provided conflicting evidence for an association between the $\mathrm{C}^{\prime}$ fixing property of anti-DNA antibodies and the presence of nephritis. ${ }^{1-5}$ The present study using a solid phase RIA showed no significant association overall. However, if those patients with low DNAb $(<30 \%)$ were excluded an association between the two variables was found to exist. This implies that in the presence of significantly raised levels of antidsDNA antibodies the ability of such antibodies to fix C3 may predispose to the development or exacerbation of nephritis. This is supported by the presence or development of active nephritis in seven out of eight of the patients with both very high DNAb and $\mathrm{C}^{\prime}$ fixing values $(>90 \%$ and $>20$ SD respectively).

Our results suggest, therefore, that quantitative measurement of $C^{\prime}$ fixation by anti-dsDNA antibodies may be both easy and useful in patients with suggested high lupus activity: it may provide in- formation about the pathogenetic role of anti- $\frac{D}{\omega}$. dsDNA antibodies in an individual patient and be a better guide to potential end organ damage than the conventional measurement of DNA binding.

We should like to thank Miss Julie Elliott, Renal Laboratory, Hammersmith Hospital, for performing $\mathrm{C} 3, \mathrm{C} 4$, and $\mathrm{CH}_{50}$ measurements.

\section{References}

1 Puritz E M, Yount W J, Newell M, Utsinger P D. Immunoglobulin classes and IgG subclasses of human antinuclear antibodies. Clin Immunol Imunopathol 1973; 2: 93-113.

2 Huber $\mathrm{O}$, Greenburg M L, Huber J. Complement-fixing ? antidouble-stranded DNA with Crithidia method: a better if indication of active SLE than anti-DNA with the Farr method. $J$ Lab Clin Med 1979; 93: 32-9.

3 Beaulieu A, Quismorio F P, Kitridou R C, Friou G J. Complement fixing antibodies to ds-DNA in systemic lupus erythematosus. J Rheumatol 1979; 6: 389-96.

4 Gharavi A E, Elkon K B, Schifferli J A, Hughes G R V. Complement fixing properties of antibodies to double-stranded $D$ DNA in systemic lupus erythematosus. J Clin Lab Immunol 1981; 6: 251-5.

5 Teppo A M, Kurki P, Helve T, Wegelius O. DNA antibodies $\vec{C}$ with and without complement-binding activity. Rheumatol Int 1984; 4: $173-6$.

6 Beaulieu A, Quismorio F P, Friou G J. IgG antibodies to double-stranded DNA in systemic lupus erythematosus sera; independent variation of complement fixing activity and antibody content. Arthritis Rheum 1979; 22: 565-70.

7 Tan E M, Cohen A S, Fries J P et al. The 1982 revised criteria for the classification of systemic lupus erythematosus. Arthritis Rheum 1982; 25: 1271-7.

8 McConahey P J, Dixon F J. A method of trace iodination of proteins for immunologic studies. Int Arch Allergy Appl Immunol 1966; 29: 185-8.

9 Fish F, Ziff M. A sensitive solid phase microradioimmunoassay for anti-double stranded DNA antibodies. Arthritis Rheum 1981; 24: 534-43.

$10 \mathrm{Vogt}$ V M. Purification and further properties of single-strandspecific nuclease from Aspergillus oryzae. Eur J Biochem 1973; 33: $192-200$.

11 Pincus T, Schur P H, Rose J A, Decker J L, Talal N. Measurement of serum DNA binding activity in SLE. $N$ Engl $J$ Med 1969: 281: 701-5.

12 Mancini G, Vaerman J P, Carbonara A O, Heremans J F. A 을 single radial diffusion method for the immunological quantitation of proteins. In: Peeter H, ed. Prot Biol Fluids 11th Colloqui 으․ Bruges 1964: 370-3.

13 Mayer M M. Complement and complement fixation. In: Kabat $\widetilde{N}$ E A. Mayer M M, eds. Experimental immunochemistry. N Springfield, Illinois, Thomas, 1961: 133.

14 Ruddy S, Carpenter C B, Chin K W, et al. Human complement $\mathrm{N}$ metabolism: an analysis of 144 studies. Medicine (Baltimore) $\sigma$ 1975; 54: 165-78.

15 Schrager M R, Rothfield N F. Clinical significance of serum properdin levels and properdin deposition in the dermal- $\mathbb{R}$ epidermal junction in systemic lupus erythematosus. J Clin $\stackrel{?}{-}$ Invest 1976; 57: 212-21.

16 Atkins C J, Kondon J J, Quismorio F P, Friou GJ. The choroid plexus in systemic lupus erythematosus. Ann Intern Med 1972; 76: $65-72$.

17 Kaffer D, Agnello V, Carr R I, Kunkel H G. Variable patterns $\stackrel{\overparen{Q}}{\varrho}$ of immunoglobulin and complement deposition in the kidneys $\sigma$ of patients with systemic lupus erythematosus. Am J Pathol $<$ 1969; 56: 305-16. 